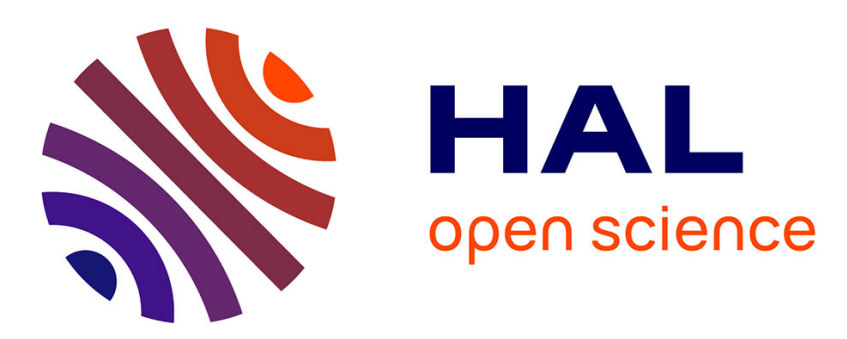

\title{
Invasion by Fallopia spp. in a French upland region is related to anthropogenic disturbances
}

\author{
S. Rouifed, F. Piola, T. Spiegelberger
}

\section{To cite this version:}

S. Rouifed, F. Piola, T. Spiegelberger. Invasion by Fallopia spp. in a French upland region is related to anthropogenic disturbances. Basic and Applied Ecology, 2014, 15 (5), p. 435 - p. 443. 10.1016/j.baae.2014.07.005 . hal-01062598

\section{HAL Id: hal-01062598 \\ https://hal.science/hal-01062598}

Submitted on 10 Sep 2014

HAL is a multi-disciplinary open access archive for the deposit and dissemination of scientific research documents, whether they are published or not. The documents may come from teaching and research institutions in France or abroad, or from public or private research centers.
L'archive ouverte pluridisciplinaire HAL, est destinée au dépôt et à la diffusion de documents scientifiques de niveau recherche, publiés ou non, émanant des établissements d'enseignement et de recherche français ou étrangers, des laboratoires publics ou privés. 
2

3

4 Soraya Rouifed ${ }^{\mathrm{a}, \mathrm{b},{ }^{*}}$, Florence Piola ${ }^{\mathrm{a}}$, Thomas Spiegelberger ${ }^{\mathrm{c}, \mathrm{d}}$

5

6 a Université de Lyon ; UMR5023 Ecologie des Hydrosystèmes Naturels et Anthropisés ; Université Lyon 1 ;

7 ENTPE ; CNRS ; 6 rue Raphaël Dubois, 69622 Villeurbanne, France.

$8{ }^{\mathrm{b}}$ Current address: Department of Plant Ecology and Evolution, Evolutionary Biology Centre, Uppsala

9 University, Uppsala, Sweden.

10 'Irstea, UR EMGR Mountain Ecosystems, 2 rue de la Papeterie-BP 76, F-38402 St-Martin-d'Hères, France

$11{ }^{\mathrm{d}}$ Ecole Polytechnique Fédérale de Lausanne (EPFL), Laboratory of Ecological Systems (ECOS) - Swiss Federal

12 Institute for Forest, Snow and Landscape Research (WSL), and Restoration Ecology Research Group, Site

13 Lausanne, station 2, CH-1015 Lausanne, Switzerland

14

\footnotetext{
* Corresponding author. Tel.: +461847100 00; fax: +4618 553419

E-mail address: soraya.rouifed@ebc.uu.se
} 
Abstract Within Europe, mountain ecosystems are generally less invaded by exotic plant species than are lowland areas. This pattern is commonly attributed to climatic harshness, which limits invasive species presence, and higher propagule pressure and rates of disturbance in lowlands, which favours dissemination. However, the extent to which anthropogenic and natural disturbances contribute to invasive species presence in mountain and lowland environments remains unclear. We conducted field observations in a lowland and an upland region in France and measured environmental variables, estimated the natural and anthropogenic disturbance of plots invaded by Fallopia spp. and compared them to non-invaded plots. Based on generalised linear mixed models, the predictors of Fallopia spp. presence in the upland area only included anthropogenic elements such as the presence of a road or trail and frequentation by humans, whereas both anthropogenic parameters and natural components (light penetration, slope, and the presence of a watercourse) were retained as predictors for the lowland region. We calculated the odds of Fallopia spp. presence for the increase of one unit of each predictor. We conclude that the spread of Fallopia spp. in upland areas was mainly linked to human activity whereas dissemination of the species occurred both through humans and in natural ways in lowland areas, and this may be due to a more recent colonisation in the mountains. We therefore advise stakeholders to undertake actions in mountain areas to specifically limit the dissemination of exotic species by humans and to monitor areas of high invasion risk by exotic species, such as areas neighbouring trails and roads highly frequented by humans.

\section{$31 \quad$ Zusammenfassung}

In Europa werden Gebirgsökosysteme im Allgemeinen weniger stark von invasiven Pflanzenarten besiedelt als tiefer gelegene Gebiete. Dieses Muster wird gemeinhin mit dem rauen Klima erklärt, das die invasiven Arten limitiert, aber auch mit der höheren Einfuhrrate von Diasporen und der größeren Störungshäufigkeit in der Ebene, was die Verbreitung fördert. Indessen ist unklar, in welchem Ausmaß anthropogene und natürliche Störungen zum Auftreten von invasiven Arten in Berg- und Flachlandgebieten beitragen. Wir führten Feldbeobachtungen in einer Berg- und einer Flachlandregion Frankreichs durch und maßen Umweltvariablen, schätzten die natürliche und anthropogene Störung von Flächen, die von Fallopia-Arten besiedelt worden waren, und verglichen diese mit unbesiedelten Flächen. Nach generalisierten linearen gemischten Modellen waren die Faktoren, die das Auftreten von Fallopia im Bergland vorhersagten, allein anthropogene Landschaftselemente wie Straßen und Wanderwege sowie die Frequentierung durch Menschen, wohingegen sowohl die anthropogenen Parameter als auch natürliche Faktoren (Lichteinfall, Hangneigung, Nähe von Fließgewässern) als Vorhersagefaktoren für das Flachland beibehalten 
45 Einheit für alle Vorhersagefaktoren. Wir schließen, dass die Verbreitung von Fallopia spp. im Bergland 46 hauptsächlich mit menschlichen Aktivitäten zusammenhing, während die Verbreitung der Arten im Flachland 47 sowohl durch den Menschen als auch auf natürliche Weise erfolgte. Dies könnte auf eine eher rezente 48 Besiedelung im Bergland zurückzuführen sein. Wir raten deshalb den Akteuren, im Bergland Maßnahmen zu 49 ergreifen, die speziell die Verbreitung exotischer Arten durch den Menschen begrenzen, und Gebiete mit hohem 50 Invasionsrisiko, wie Flächen entlang von stark von Menschen frequentierten Wanderwegen und Straßen zu 51 überwachen.

52

53 Keywords: invasibility, Japanese knotweeds s.l., mountains, odds ratios, roads, watercourses 54 
The growing frequency of human exchanges is leading to the spread of more species' propagules worldwide. Some exotic species become established and proliferate in their new range, leading in many cases to competition with native species, to modifications of ecosystem functioning and to substantial losses in agricultural production (Pyšek \& Hulme 2005). Because of the impacts of invasive species, many management plans intend to prevent further spread. However, data to assess the invasibility of some ecosystems is often lacking, which hampers predictions of the future distribution of invasive species. For that purpose, key factors involved in the invasion risk have to be identified. Knowledge of the current distribution, related to landscape or environmental characteristics of invaded ecosystems, may help to identify these factors. Invasion is the result of the interaction between propagule pressure, abiotic characteristics of the invaded ecosystem, and biotic characteristics of the recipient community and the invading species. These drivers fluctuate across space and time, and are likely to be influenced by humans (Catford, Jansson \& Nilsson 2009). Among abiotic factors, disturbance is noted as a key factor favouring the colonisation and establishment of invasive species because it creates niche opportunities (Hobbs \& Huenneke 1992), and sometimes dispersal opportunities (for example during the construction of roads and buildings, Arévalo, Otto, Escudero, FernándezLugo, Arteaga et al. 2010). Disturbance can be caused by natural events, such as floods and herbivory, or can be anthropogenic, such as changes in land use, management and fertilisation (Lockwood, Hoopes \& Marchetti 2007). In Europe, human population density and intensity of human activities appeared to well explain plant invasions (Pyšek, Jarosik, Hulme, Kuhn, Wild et al. 2010), showing the great impact of anthropogenic disturbances.

In temperate areas, it appears that invasive plant species richness is lower in mountain ecosystems than in lowlands, but tends to increase (Pauchard, Kueffer, Dietz, Daehler, Alexander et al. 2009). It is not clear whether this is a result of a time lag (stage of invasion), of reduced propagule pressure or of abiotic and biotic conditions in mountains. Indeed, along altitudinal gradients, the relative importance of factors influencing invasions is likely to change (Pauchard et al. 2009). For example, decreasing temperature constrains invasive plant richness in elevated regions (Marini, Gaston, Prosser \& Hulme 2009). The effects of disturbances are uncertain, because anthropogenic disturbances, together with human population density, are assumed to decrease with elevation, while natural physical disturbance, such as landslide or rock falls, are assumed to increase 


\section{Study areas}

\section{3}

114 The departments of Loire and Isere, two neighbouring departments situated in the southeastern part of France,

disturbances on the presence of invasive species are the same in mountain and lowland environments (Pauchard et al. 2009). Thus, studies comparing links between disturbances and presence of invasive species in lowland and upland sites are needed to clarify the role of disturbances in invasibility along an altitudinal gradient.

Japanese knotweeds s.l. (Fallopia japonica (Houtt.) Ronse Decraene (Japanese knotweed s.s.), Fallopia sachalinensis (F. Schmidt ex Maxim.) Ronse Decraene and the hybrid Fallopia x bohemica (Chrtek and Chrtková); herein after referred to as Fallopia spp. or knotweed) are widespread invaders in North America (Shaw \& Seiger 2002) and Europe (Child \& Wade 2000) where they are classified among the 20 most frequent weeds (Lambdon, Pysek, Basnou, Hejda, Arianoutsou et al. 2008). Large economic (Crowhurst 2006), faunistic and floristic (Gerber, Krebs, Murrell, Moretti, Rocklin et al. 2008) impacts have been identified following its invasion. Studying Fallopia spp. in the context of disturbances in elevated areas is interesting because they are pioneer species, which regenerate easily from rhizomes and stem fragments (Bímová, Mandák \& Pyšek 2003). These plants generally occur in their invasive range in riparian habitats and in many types of anthropogenically disturbed habitats, mainly along roads and railways (Bailey, Bímová \& Mandák 2009). In addition, in elevated areas, Fallopia spp. are not likely to be constrained by climate, as they seem to be cold tolerant (absolute minimum temperature $-30,2^{\circ} \mathrm{C}$, Beerling, Huntley \& Bailey 1995).

In the present study, we focus on the importance of human and natural disturbances for the presence of Fallopia spp. in lowland and upland sites. We hypothesize that Fallopia spp. presence is better explained by disturbances than by environmental variables such as light availability above the plots, slope inclination and soil granulometry (indicator of the capacity of the soil to retain water). We further postulate that in lowland areas human disturbances (frequentation by humans, presence of working areas, roads and trails) increase the probability of Fallopia spp. presence compared to natural disturbances (watercourses and erosion). In contrast, we assume for upland areas that natural disturbances mainly influence Fallopia spp. presence.

\section{Materials and methods} were the study areas. In the Loire department, crossed from south to north by the river Loire, which is highly 
116 invaded by Fallopia spp., 29 sites were chosen by randomly generating four to six points at a distance of

117 approximately $10 \mathrm{~km}$ along six east-west transects (two transects in the northern region, two in the centre and

118 two in the southern part of the department). Starting from these points, the nearest physically accessible site

119 containing Fallopia spp. was surveyed in the field. When no invaded site was visible in the field, the nearest

120 invaded site listed in the botanical inventory by the National Botanical Conservatory of Massif Central was

121 surveyed. In the department of Isere, based on an inventory performed by the National Botanical Conservatory

122 of the Alps, 60 sites were recorded above an elevation of approximately $800 \mathrm{~m}$ (cf. http://renouee.cemagref.fr).

123 See Appendix A. for locations of studied sites.

124

125 Plot arrangement and variables measured

126

127 Each of the 89 sites included two paired plots ( $25 \times 25$ m each), one invaded by Fallopia spp. and the other non-

128 invaded. At each site, the centre of the Fallopia spp. patch and the plot centre were congruent. A non-invaded

129 plot was randomly chosen near the invaded plot; the centres of each plot were within a distance of $50 \mathrm{~m}$ (Fig.1).

130 Plots found to be infested within the surrounding plots were rejected and subsequently recorded as Fallopia spp.

131 infestations.

132 In the invaded plots, the total area occupied by Fallopia spp. was measured. The GPS coordinates and 133 elevation were recorded for both the invaded and non-invaded plots. The slope inclination was visually estimated 134 into four classes (none/low/intermediate/steep) and the slope aspect to the nearest $45^{\circ}$ from north. Light 135 penetration in the plot was visually estimated to the nearest $10 \%$ by estimating the vertically projected cover of 136 the woody layer. The frequentation by humans at the site was visually assessed and recorded into three classes 137 (low, intermediate, high). Visible erosion was noted. The distance to the nearest tarred road, dirt track or trail, 138 watercourse and working area (including road works, settlements or timber stocking areas) were recorded in the 139 field when visible; otherwise, the distance was calculated using a GIS application. The maximal distance was 140 fixed at $9999 \mathrm{~m}$. Sampling occurred from August to September 2008 in both departments; in October 2009 , 141 three additional sites were recorded in Isere.

142 Three soil cores (depth of $10 \mathrm{~cm}$, diameter of $7 \mathrm{~cm}$ ) were collected from each plot and pooled. The soil 143 samples were dried for 48 hours at $70{ }^{\circ} \mathrm{C}$ before fractionation into five classes: silt and clay $(0-63 \mu \mathrm{m})$, sand $(63$ $144 \mu \mathrm{m}-2 \mathrm{~mm})$, granules $(2-4 \mathrm{~mm})$, gravel $(4-64 \mathrm{~mm})$ and pebbles $(>64 \mathrm{~mm})$. Each fraction was weighted, and its 145 percentage of the total soil mass was calculated. 
Data analysis

149 Based on the distance to roads, trails, watercourses, and working areas, the Fallopia spp. presence within a 150 radius of 10,50 , and $100 \mathrm{~m}$ for roads, trails, and watercourses and of $50 \mathrm{~m}$ for working areas was derived. Plots in which a road, trail or working area were present within the above-mention radii were considered as "disturbed by humans", whereas plots in which soil erosion was visible or a watercourse was present were considered as "naturally disturbed". elevation of approximately $900 \mathrm{~m}$, corresponding to the limit between the collinean and the montane zones in the region (Ozenda 1985). The lowland data set (number of plots $\mathrm{N}=92$ ) contained the paired plots for which the invaded plot was situated below $895 \mathrm{~m}$, and the other plots formed the upland data set (number of plots $\mathrm{N}=86$ ).

158 The significant differences between the lowland and upland sites were tested using the t-test for each variable.

159 Due to the topography of the two departments, the majority of lowland sites are situated in Loire and the 160 majority of upland sites are situated in Isere. However, because the departments are adjacent, have similar mean 161 temperatures and precipitations, and because we compared invaded plots and control plots within sites (GLMM analyses), we are confident that the results are not flawed by the departments.

Three generalized linear mixed models (GLMMs) were calculated: a global model for the entire data set

164 and one model each for the upland and lowland data sets. The response variable Fallopia spp. presence and absence were analysed using a logistic model, with logit as the link function, and with site as random factor. The variables included in the analyses are shown in Table 1. Of the five soil classes, only the percentage of gravel and the percentage of sand were retained in the analysis because the percentage of silt and clay and the percentage of granules were highly correlated to the percentage of sand (Pearson correlation, for both $\mathrm{P}<0.001$; correlation coefficient $>0.95$ ). The percentage of pebbles was excluded from the analysis, as pebbles were only present in $3.4 \%$ of all the soil samples. Forward selection was used to determine the best combination of predictors for a minimal model.

For the entire data set and for each region, we analysed for each potential risk factor the conditions

173 under which the plots were invaded by Fallopia spp. relative to the non-invaded plots. The coefficient estimates

174 of each risk factor in the GLMM can be interpreted as the logarithm of the odds ratios of a plot containing

175 Fallopia spp. if the other predictors were constant (Quinn \& Keough 2002). The "odds ratio" is the ratio of the 

areas, are illustrated in Table 1.

188

\section{Results}

Differences between lowland and upland sites Table 1). plots were slightly richer in soil pebble (Table 1). not significantly differ (Table1).

odds of a plot containing Fallopia spp. if exposed to one level of a risk factor relative to the odds of a plot not containing Fallopia spp. if exposed to the next level of the same risk factor. Thus, an odds ratio of two for a factor means that, for every increase in one unit of that risk factor, the odds of a plot containing Fallopia spp. doubles. All the analyses were performed using R statistical language (R Development Core Team 2012).

The characteristics of the lowland and the upland plots, and the significance of the differences between the two

The altitude of the lowest plot (in the lowland area) was $276 \mathrm{~m}$, and the highest plot was elevated by $1665 \mathrm{~m}$ (upland area). There was no significant difference between the area of the invaded plots of the lowland and of the upland, although invaded plots of lowland (mean: $210 \mathrm{~m}^{2}$ ) tended to be larger (mean in upland: $109 \mathrm{~m}^{2}$,

At all sites (control and invaded), light penetration was lower in the upland plots, leading to more shading on the plots. The slope inclination was higher in lowland sites. The analysis of soil granulometry showed that upland

The most striking differences were found concerning the human impact near the plots. In the upland region, the invaded plots and their paired control sites were situated in closer vicinity to working areas and trails compared to plots in the lowland area (Table 1), indicating the importance of human disturbance for the colonisation of the upland region by knotweed. In contrast, the lowland and upland sites showed no significant differences in estimated frequentation or distance to nearest road (Table 1).

Lowland and upland plots showed no significant differences concerning natural disturbances. All plots were situated near a watercourse, and the distance to the nearest watercourse and the frequency of eroded zones did 

spp. presence belonged to three classes: environmental variables (light penetration), natural disturbance (presence of a watercourse), and human disturbance (frequentation by humans, presence of a road or trail). However, analysing the upland and lowland sites separately led to different predictors of knotweed presence for both regions (Table 2). Only anthropogenic elements, such as the presence of a road or a trail within a radius of

$21110 \mathrm{~m}$ and the frequentation by humans in the surroundings of the plot, were retained in the reduced GLMM for 212 the upland region while for the lowland region both anthropogenic and natural components, such as light 213 penetration, slope inclination, and the presence of a watercourse within a radius of $10 \mathrm{~m}$, were retained as 214 predictors.

Factors increasing the odds of a plot containing knotweeds

In the global analysis that included all sites, the odds of a plot containing Fallopia spp. increased with increasing light penetration, with the presence of a road, a trail or a watercourse, and with a high frequentation by humans (Table 3). For the upland plots, a shift from low frequentation to intermediate or similarly from intermediate to high frequentation by humans increased more than four times the probability of encountering knotweeds. Frequentation by humans represented the factor with the highest leverage, while the presence of a trail in the plot vicinity nearly doubled, and the presence of a road increased the same probability by about $50 \%$ (Table 3 ). For the lowland plots, the presence of a river within $10 \mathrm{~m}$ and the presence of a road more than doubled the odds of a plot containing knotweeds. However, increasing slope inclination from low to intermediate augmented by about

2268 the odds ratio and by about 11 when intermediate slopes became steep ones, but these numbers have to be interpreted with caution as their variability, indicated by the large range of the confidence interval, is high.

228 Compared to these high odds, increasing light availability by $10 \%$ had hardly any effect on Fallopia presence (Table 3) even when light availability was retained as a significant factor in the GLMM (Table 2).

\section{Discussion}


Species belonging to the genus Fallopia spp. are supposed to greatly benefit from disturbance outside their native range because of their high colonisation potential, allowing them to dominate such areas rapidly (Tiébré,

238 Saad \& Mahy 2008). In accordance with our first hypothesis, the presence of Fallopia spp. is, to a large extent, explained in this study by disturbances of both natural (watercourse) and human (trails, roads, frequentation) origin. Close associations between knotweeds and human disturbance along rail or road infrastructures (Bímová, Mandák \& Kašparová 2004, Tiébré et al. 2008) and knotweed and naturally disturbed watercourses (Beerling 242 1991) have been reported. Road infrastructures may serve as vectors of alien species dispersal (Arévalo et al. 243 2010, Coffin 2007); similarly, watercourses may contribute to the dispersal of alien propagules (Richardson, 244 Holmes, Esler, Galatowitsch, Stromberg et al. 2007) and, in particular, of knotweed achenes (Rouifed, Puijalon, 245 Viricel \& Piola 2011). Moreover, the hydraulic dynamics of watercourses, which lead to temporarily reduced 246 competition for space and high resource availability on banks, make those sites important habitats for alien species (Richardson et al. 2007).

Our study compared two disturbance types that influence the presence of Fallopia spp. at different elevations. Although the global analysis, including all the low- and upland sites, indicated both human and natural disturbances as predominant, the separate analyses clearly suggested different predictors for knotweed presence at the two levels of elevation. Contrary to our hypothesis, natural disturbance and its associated factors did not explain the presence of Fallopia spp. in the upland areas, confirming that it is difficult to predict what type of disturbance will be predominant based on the elevation of the area (Pauchard et al. 2009). Indeed, several studies highlight the importance of anthropogenic disturbance in explaining plant invasions in mountains (Alexander, Naylor, Poll, Edwards \& Dietz 2009, Arévalo et al. 2010).

The pattern of our results is consistent with the directional ecological filtering hypothesis (Alexander, Kueffer, Daehler, Edwards, Pauchard et al. 2011), which states that the colonisation of mountains by non-native species is the result of the dispersal from lowland sources of species with wide elevational amplitude. Directional ecological filtering implies firstly that species reaching higher elevations are good dispersers and secondly that these species must also have wide climatic tolerance because they are able to establish populations across the full elevational gradient (Alexander et al. 2011). The case of Fallopia spp. fits these assumptions.

262 First, they are able to efficiently disperse both asexually and sexually (Bailey et al. 2009). In our study, roads and trails explained the presence of the species and may be more important dispersal pathways than sites of 264 niche opportunities: rhizome fragments of Fallopia spp. could easily be dispersed through soil transport and engine circulation during construction works and possibly by foot-traffic dispersing stem fragments and seeds. 
Second, Fallopia spp. have wide climatic tolerance: Fallopia japonica can resist cold temperatures up to a minimum threshold estimated between -32.0 and $-25.8^{\circ} \mathrm{C}$ (Beerling et al. 1995). Although we did not measure the temperatures or other climatic variables in upland and lowland regions, we assume that the pattern of the presence of the species would not be influenced by the different climates because of their wide climate tolerance, which is corroborated by the presence of Fallopia spp. up to $1600 \mathrm{~m}$ asl.

In contrast to the upland region, where solely anthropogenic disturbances factors explained the presence of knotweeds, both human disturbances, natural disturbances, and other environmental factors such as light penetration and slope inclination were important in the lowland region. We deduce from greater variety of the

274 predictive factors that the invasion process of Fallopia spp. is older at low elevation. In the lowland, the spread of Fallopia spp. appeared to be under "natural" regulation and no longer only linked to human presence: knotweeds may have reached the stage of propagation in the landscape (stages sensu Theoharides \& Dukes 2007), whereas the invasion process appeared not to have exceeded the stages of colonisation or establishment in the mountainous regions. In the latter spread is perhaps beginning, related to anthropogenic disturbances, as vectors of niche opportunities and propagules' dispersers.

The influence of light penetration and slope inclination in the lowland region can be interpreted as another evidence of natural dispersal: Fallopia spp. is favoured on sites with a high disturbance rate, as steep slopes are mainly found along rivers with high erosion activity, and with high light availability, indicating less tree and shrub cover to shade Fallopia spp. stands. Indeed, knotweeds are pioneer species in their native range, colonising sites with a high light availability (Adachi, Terashima \& Takahashi 1996) and rarely dominate in their exotic range in mature forests, which filter a significant portion of photons (McClain, Holl \& Wood 2011). Light availability, therefore, appears to be one of the factors that might directly affect the frequency and the cover of exotic species (McClain et al. 2011; Dommanget, Spiegelberger, Cavaillé \& Evette 2013) which is confirmed by our findings. Consequently, succession that shifts the understory from light-demanding to shade-tolerant species may limit colonisation by invasive species (McClain et al. 2011).

Our study did not allow a distinction between light availability as the cause or consequence of Fallopia spp. presence. One may interpret the higher light availability at invaded sites as the consequence of a process of 292 competitive exclusion induced by knotweed, leading to a lower cover of trees and shrubs and, consequently, a 293 higher light penetration. However, as described above, it may also be that knotweeds in particular invade sites 294 with high light availability (no or only low tree/shrub cover), which may be interpreted as the result of a disturbance or as an earlier successional stage that is more prone to invasion (Rejmánek 1989). In our study, the 
odds of Fallopia presence with an increase of $10 \%$ of light availability were low, which may seem inconsistent with the high influence of light in models explaining the presence of the plant. A connection between disturbances and light may explain this paradox.

To conclude, our study clearly shows the link between human activities and the presence of Fallopia spp. in a mountainous region, contrary to a lowland region where biotic variables and natural disturbance are involved. Future studies are necessary to precise the relative importance of time, as different kinds of disturbances may be involved at different stages of the invasion process, and of abiotic factors, such as nutrient composition and hydraulic variables, which may differ in lowland and upland regions.

Invasion risk and advice to stakeholders

The results of our study indicate that (i) natural or anthropogenic disturbance plays a key role in explaining the presence of Fallopia spp. and (2) the importance of the origin of the disturbance differs at low and high elevations. In light of this, we recommend surveying of steep river banks next to roads in lowland regions and highly frequented sites neighbouring roads and trails above $900 \mathrm{~m}$ where invasion risk by Fallopia spp. is high. European mountains are one of the few ecosystems where a proactive management strategy is still possible (McDougall, Khuroo, Loope, Parks, Pauchard et al. 2011). Early detection surveys in such zones as those described above where invasion risk is high and the elimination of a few individuals when eradication is still possible are most likely more cost effective than attempts of eradication or control once invasion has occurred (Wittenberg \& Cook 2001).

\section{Acknowledgments}

We thank two anonymous referees for useful comments on the manuscript. We are grateful to the National Botanical Conservatory in Gap-Charente and the Botanical Association Gentiana for providing the presence data for Isere and National Botanical Conservatory of Massif Central for providing the presence data for Loire. We thank B. Bardy, S. Bibollet, N. Daumergue, F. Vallier and G. Prost for fieldwork. We thank Irstea, Conseil général de l'Isère, FEDER, Agence de l'Eau Loire-Bretagne, Conseil général de la Loire and Région RhôneAlpes for financial support. 
327 Supplementary data associated with this article can be found, in the online version, at 328 
331 Adachi, N., Terashima, I., \& Takahashi, M. (1996). Central die-back of monoclonal stands of Reynoutria

332 japonica in an early stage of primary succession on Mount Fuji. Annals of Botany, 77, 477-486.

333 Alexander, J.M., Kueffer, C., Daehler, C.C., Edwards, P.J., Pauchard, A., Seipel, T., \& Consortium, M. (2011).

334 Assembly of nonnative floras along elevational gradients explained by directional ecological filtering.

Proceedings of the National Academy of Sciences of the United States of America, 108, 656-661.

Alexander, J.M., Naylor, B., Poll, M., Edwards, P.J., \& Dietz, H. (2009). Plant invasions along mountain roads: 344.

Arévalo, J.R., Otto, R., Escudero, C., Fernández-Lugo, S., Arteaga, M., Delgado, J.D., \& Fernández-Palacios, J.M. (2010). Do anthropogenic corridors homogenize plant communities at a local scale? A case studied in

341 Tenerife (Canary Islands). Plant Ecology, 209, 23-35.

342 Bailey, J.P., Bímová, K., \& Mandák, B. (2009). Asexual spread versus sexual reproduction and evolution in

343 Japanese Knotweed s.l. sets the stage for the "Battle of the Clones". Biological Invasions, 11, 1189-1203.

344 Beerling, D.J. (1991). The effect of riparian land-use on the occurence and abundance of Japanese Knotweed

345 Reynoutria Japonica on selected rivers in South Wales. Biological Conservation, 55, 329-337.

346 Beerling, D.J., Huntley, B., \& Bailey, J.P. (1995). Climate and the Distribution of Fallopia-Japonica : Use of an 347 Introduced Species to Test the Predictive Capacity of Response Surfaces. Journal of Vegetation Science, 6, 269$348 \quad 282$.

349 Bímová, K., Mandák, B., \& Kašparová, I. (2004). How does Reynoutria invasion fit the various theories of 350 invasibility? Journal of Vegetation Science, 15, 495-504.

351 Bímová, K., Mandák, B., \& Pyšek, P. (2003). Experimental study of vegetative regeneration in four invasive 352 Reynoutria taxa (Polygonaceae). Plant Ecology, 166, 1-11. 
Child, L.E., \& Wade, M. (2000). The Japanese knotweed manual. Chichester: Packard Publishing Limited.

366 Hobbs, R.J., \& Huenneke, L.F. (1992). Disturbance, Diversity, and Invasion - Implications for Conservations.

368 Lambdon, P.W., Pysek, P., Basnou, C., Hejda, M., Arianoutsou, M., Essl, F., Jarosik, V., Pergl, J., Winter, M., 369 Anastasiu, P., Andriopoulos, P., Bazos, I., Brundu, G., Celesti-Grapow, L., Chassot, P., Delipetrou, P., 370 Josefsson, M., Kark, S., Klotz, S., Kokkoris, Y., Kuhn, I., Marchante, H., Perglova, I., Pino, J., Vila, M., Zikos, 371 A., Roy, D., \& Hulme, P.E. (2008). Alien flora of Europe: species diversity, temporal trends, geographical 372 patterns and research needs. Preslia, 80, 101-149.

374 Marini, L., Gaston, K.J., Prosser, F., \& Hulme, P.E. (2009). Contrasting response of native and alien plant 375 species richness to environmental energy and human impact along alpine elevation gradients. Global Ecology and Biogeography, 18, 652-661. 
379 McDougall, K.L., Khuroo, A.A., Loope, L.L., Parks, C.G., Pauchard, A., Reshi, Z.A., Rushworth, I., \& Kueffer,

380 C. (2011). Plant Invasions in Mountains: Global Lessons for Better Management. Mountain Research and 381 Development, 31, 380-387.

382 Ozenda, P. (1985). Die Vegetation der Alpen im europäischen Gebirgsraum. Stuttgart - New York: Gustav 383 Fischer.

384 Pauchard, A., Kueffer, C., Dietz, H., Daehler, C.C., Alexander, J., Edwards, P.J., Arevalo, J.R., Cavieres, L.A., 385 Guisan, A., Haider, S., Jakobs, G., McDougall, K., Millar, C.I., Naylor, B.J., Parks, C.G., Rew, L.J., \& Seipel, T. 386 (2009). Ain't no mountain high enough: plant invasions reaching new elevations. Frontiers in Ecology and the 387 Environment, 7, 479-486.

388 Pyšek, P., \& Hulme, P.E. (2005). Spatio-temporal dynamics of plant invasions: Linking pattern to process. 389 Ecoscience, 12, 302-315.

390 Pyšek, P., Jarosik, V., Hulme, P.E., Kuhn, I., Wild, J., Arianoutsou, M., Bacher, S., Chiron, F., Didziulis, V., 391 Essl, F., Genovesi, P., Gherardi, F., Hejda, M., Kark, S., Lambdon, P.W., Desprez-Loustau, M.L., Nentwig, W., 392 Pergl, J., Poboljsaj, K., Rabitsch, W., Roques, A., Roy, D.B., Shirley, S., Solarz, W., Vila, M., \& Winter, M. 393 (2010). Disentangling the role of environmental and human pressures on biological invasions across Europe. 394 Proceedings of the National Academy of Sciences of the United States of America, 107, 12157-12162.

395 Quinn, G.P., \& Keough, M.J. (2002). Experimental design and data analysis for biologists. Cambridge: 396 Cambridge University Press.

397 R Development Core Team (2012). R: A language and environment for statistical computing. R Foundation for 398 Statistical Computing, Vienna, Austria. ISBN 3-900051-07-0, URL http://www.R-project.org/.

399 Rejmánek, M. (1989). Invasibility of plant communities. In: J.A. Drake, H.A. Mooney, F. di Castri, R.H. 400 Groves, F.J. Kruger, M. Rejmánek, \& M. Williamson (Eds.), Biological invasion. A global perspective (pp. 369401 388). Chichester, UK: John Wiley and Sons. 
402 Richardson, D.M., Holmes, P.M., Esler, K.J., Galatowitsch, S.M., Stromberg, J.C., Kirkman, S.P., Pysek, P., \&

403 Hobbs, R.J. (2007). Riparian vegetation: degradation, alien plant invasions, and restoration prospects. Diversity

404 and Distributions, 13, 126-139.

405 Rouifed, S., Puijalon, S., Viricel, M.R., \& Piola, F. (2011). Achene buoyancy and germinability of the terrestrial 406 invasive Fallopia $\mathrm{x}$ bohemica in aquatic environment: A new vector of dispersion? Ecoscience, $18,79-84$.

407 Shaw, R.H., \& Seiger, L.A. (2002). Japanese knotweed. In: R. Van Driesche, B. Blossey, M. Hoddle, S. Lyon, \& 408 R. Reardon (Eds.), Biogical Control of invasive plants in the eastern United States, (p. 413): USDA Forest 409 Service Publication.

410 Theoharides, K.A., \& Dukes, J.S. (2007). Plant invasion across space and time: factors affecting nonindigenous 411 species success during four stages of invasion. New Phytologist, 176, 256-273.

412 Tiébré, M.S., Saad, L., \& Mahy, G. (2008). Landscape dynamics and habitat selection by the alien invasive 413 Fallopia (Polygonaceae) in Belgium. Biodiversity and Conservation, 17, 2357-2370.

414 Wittenberg, R., \& Cook, M.J.W. (2001). Invasive alien species: a toolkit of best prevention and management 415 practices. Wallington, Oxon: CAB International.

416

417 
419 Fig. 1. Schematic representation of invaded and control plots location in one site.

$420 \quad F$ represents the invaded plot. Associated control plot was randomly chosen among the 16 areas defined around

421 the invaded plot. Measurements were carried out in a $25 \times 25$ metres square in both plots. 


\begin{tabular}{|c|c|c|c|c|}
\hline 1 & 2 & 3 & 4 & 5 \\
\hline 16 & & $5 \mathrm{~m}$ & & 6 \\
\hline 15 & & $\mathbf{F}$ & & 7 \\
\hline 14 & & & & 8 \\
\hline 13 & 12 & 11 & 10 & 9 \\
\hline
\end{tabular}




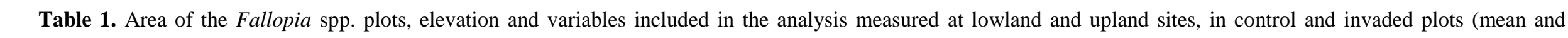
standard error). The P-values indicate the significance of t-tests between the lowland and upland sites (control and invaded plots are considered together).

\begin{tabular}{|c|c|c|c|c|c|c|c|c|c|c|}
\hline \multirow[t]{3}{*}{ Variable } & \multirow[t]{3}{*}{ Unit } & \multicolumn{4}{|c|}{ Lowland } & \multicolumn{4}{|c|}{ Upland } & \multirow{3}{*}{$\begin{array}{r}\text { Lowland vs Upland } \\
\text { P value }\end{array}$} \\
\hline & & \multicolumn{2}{|c|}{ Control } & \multicolumn{2}{|c|}{ Invaded } & \multicolumn{2}{|c|}{ Control } & \multicolumn{2}{|c|}{ Invaded } & \\
\hline & & Mean & SE & Mean & $\mathrm{SE}$ & Mean & SE & Mean & SE & \\
\hline Area of invaded plots & Square metres & - & - & 210.5 & 53.5 & - & - & 109.3 & 22.6 & 0.087 \\
\hline Elevation & Metres & 630 & 35 & 629 & 34 & 1049 & 29 & 1050 & 29 & $<0.001$ \\
\hline \multicolumn{11}{|l|}{ Environment } \\
\hline Slope inclination & Flat $(0) /$ low(1)/intermediate(2)/steep(3) & 1.3 & 0.2 & 1.8 & 0.2 & 1.3 & 0.2 & 1.3 & 0.2 & 0.034 \\
\hline Light penetration & Percentage & 59.2 & 5.7 & 62.3 & 5.0 & 27.2 & 5.1 & 27.6 & 3.7 & $<0.001$ \\
\hline Soil pebbles & Proportion & 0.53 & 0.03 & 0.52 & 0.03 & 0.60 & 0.04 & 0.60 & 0.03 & 0.047 \\
\hline Soil granules & Proportion & 0.14 & 0.01 & 0.15 & 0.01 & 0.12 & 0.01 & 0.13 & 0.01 & 0.260 \\
\hline Soil sand & Proportion & 0.32 & 0.03 & 0.33 & 0.03 & 0.28 & 0.03 & 0.26 & 0.02 & 0.066 \\
\hline \multicolumn{11}{|l|}{ Human disturbance } \\
\hline Human disturbance & Presence(1)/Absence(-1) & 0.4 & 0.1 & 0.6 & 0.1 & 0.9 & 0.1 & 0.9 & 0.1 & 0.009 \\
\hline Frequentation & $\operatorname{Low}(-1)$, intermediate $(0), \operatorname{high}(1)$ & -0.1 & 0.1 & 0.5 & 0.1 & -0.3 & 0.1 & 0.1 & 0.1 & 0.688 \\
\hline Working area & Presence(1)/Absence(-1) & 0.1 & 0.1 & -0.1 & 0.1 & 0.6 & 0.1 & 0.7 & 0.1 & $<0.001$ \\
\hline \multicolumn{11}{|l|}{ Distance to the nearest } \\
\hline working area & Metres & 5659 & 738 & 5224 & 743 & 2093 & 628 & 1628 & 570 & $<0.001$ \\
\hline Working area within $50 \mathrm{~m}$ & Presence(1)/Absence(-1) & -0.2 & 0.1 & -0.1 & 0.1 & 0.6 & 0.1 & 0.7 & 0.1 & $<0.001$ \\
\hline Road & Presence(1)/Absence(-1) & 1.0 & 0.1 & 1.0 & 0.1 & 1 & 0 & 1 & 0 & 0.323 \\
\hline Distance to the nearest road & Metres & 25.8 & 4.8 & 14.7 & 4.1 & 21.0 & 4.6 & 13.5 & 3.8 & 0.823 \\
\hline Road within $10 \mathrm{~m}$ & Presence(1)/Absence(-1) & -0.3 & 0.1 & 0.3 & 0.1 & 0.1 & 0.1 & 0.4 & 0.1 & 0.490 \\
\hline Road within $50 \mathrm{~m}$ & Presence(1)/Absence(-1) & 0.8 & 0.1 & 0.9 & 0.1 & 0.7 & 0.1 & 0.8 & 0.1 & 0.410 \\
\hline
\end{tabular}




$\begin{array}{ll}\text { Road within } 100 \mathrm{~m} & \text { Presence(1)/Absence(-1) } \\ \text { Trail } & \text { Presence(1)/Absence(-1) } \\ \text { Distance to the nearest trail } & \text { Metres } \\ \text { Trail within } 10 \mathrm{~m} & \text { Presence(1)/Absence(-1) } \\ \text { Trail within } 50 \mathrm{~m} & \text { Presence(1)/Absence(-1) } \\ \text { Trail within } 100 \mathrm{~m} & \text { Presence(1)/Absence(-1) }\end{array}$

\begin{tabular}{rrrrrrrrr}
0.9 & 0.1 & 0.9 & 0.1 & 0.9 & 0.1 & 1 & 0 & 0.160 \\
0.1 & 0.1 & -0.1 & 0.1 & -0.5 & 0.1 & -0.4 & 0.1 & 0.084 \\
2466 & 630 & 2462 & 630 & 321 & 231 & 309 & 231 & $\mathbf{0 . 0 0 2}$ \\
-0.6 & 0.1 & -0.2 & 0.1 & -0.7 & 0.1 & -0.4 & 0.1 & 0.362 \\
-0.2 & 0.1 & -0.1 & 0.1 & -0.3 & 0.1 & 0.2 & 0.1 & 0.777 \\
-0.1 & 0.1 & 0.1 & 0.1 & 0.2 & 0.1 & 0.3 & 0.1 & 0.220 \\
& & & & & & & & \\
-0.6 & 0.1 & -0.2 & 0.1 & -0.5 & 0.1 & -0.8 & 0.1 & 0.281 \\
1 & 0 & 1 & 0 & 1 & 0 & 1 & 0 & 0.999 \\
& & & & & & & & \\
1170 & 460 & 1165 & 460 & 371 & 230 & 366 & 231 & 0.126 \\
-0.8 & 0.1 & -0.4 & 0.1 & -0.7 & 0.1 & -0.5 & 0.1 & 0.594 \\
0.1 & 0.1 & 0.1 & 0.1 & -0.2 & 0.1 & -0.1 & 0.1 & 0.344 \\
0.4 & 0.1 & 0.3 & 0.1 & 0.1 & 0.1 & 0.2 & 0.1 & 0.641 \\
-0.8 & 0.1 & -0.7 & 0.1 & -0.8 & 0.1 & -0.9 & 0.1 & 0.344 \\
\hline
\end{tabular}


1 Table 2. Factors influencing the presence of Fallopia spp. in an upland region of France, a lowland region and in 2 all sites (GLMM analysis). Df: degrees of freedom. $\chi$ : Chi-value. P: P-value. The asterisks indicate the degree of 3 significance: ${ }^{\circ} \mathrm{P}<0.1, * \mathrm{P}<0.05, * * \mathrm{P}<0.01, * * * \mathrm{P}<0.001$

4

\begin{tabular}{|c|c|c|c|c|c|c|c|c|c|c|c|c|}
\hline \multirow[b]{3}{*}{ Presence of a watercourse within $10 \mathrm{~m}$} & \multicolumn{4}{|c|}{ All Sites } & \multicolumn{4}{|c|}{ Upland } & \multicolumn{4}{|c|}{ Lowland } \\
\hline & $\overline{\mathrm{Df}}$ & $\bar{\chi}$ & $\mathrm{P}$ & & $\overline{\mathrm{D} 1}$ & $\chi$ & $\bar{P}$ & & $\overline{\mathrm{Df}}$ & $\chi$ & $\bar{P}$ & \\
\hline & 1 & 4,1 & 0,043 & * & & & ------- & & 1 & 5,3 & 0,021 & * \\
\hline Presence of a road within $10 \mathrm{~m}$ & 1 & 11,0 & $<0,001$ & $* * *$ & 1 & 3,7 & 0,055 & $\circ$ & 1 & 8,6 & 0,003 & ** \\
\hline Presence of a trail within $10 \mathrm{~m}$ & 1 & 3,9 & 0,050 & * & 1 & 4,2 & 0,040 & * & & & ------ & \\
\hline Frequentation & 2 & 11,6 & 0,003 & $* *$ & 2 & 8,4 & 0,015 & $* *$ & 2 & 5,1 & 0,078 & $\circ$ \\
\hline Light penetration & 1 & 4,3 & 0,039 & $*$ & & & ------- & & 1 & 10,5 & 0,001 & $* *$ \\
\hline Slope inclination & & & ------ & & & & ------ & & 3 & 9,5 & 0,023 & ** \\
\hline Residuals & 171 & & & & 81 & & & & 83 & & & \\
\hline
\end{tabular}


1 Table 3. Odds-ratios for factors influencing the odds to find a plot containing Fallopia spp. for all sites, lowland 2 sites and upland sites (95\% confidence intervals are indicated in parentheses).

3

\begin{tabular}{llll}
\hline & \multicolumn{2}{c}{ Sites } \\
\cline { 2 - 4 } & All & Upland & Lowland \\
\cline { 2 - 4 } Presence of a watercourse within $10 \mathrm{~m}$ & $1.57(1.01-2.44)$ & --- & $2.67(1.16-6.16)$ \\
Presence of a road within $10 \mathrm{~m}$ & $1.77(1.26-2.47)$ & $1.62(0.99-2.64)$ & $2.29(1.32-3.96)$ \\
Presence of a trail within $10 \mathrm{~m}$ & $1.53(1.00-2.35)$ & $1.91(1.03-3.53)$ & --- \\
Shifting from no frequentation to low frequentation & $3.38(1.53-7.47)$ & $4.76(1.52-14.90)$ & $4.28(1.03-17.78)$ \\
Shifting from low to intermediate frequentation & $3.92(1.60-9.64)$ & $4.37(1.27-15.09)$ & $5.66(1.12-28.62)$ \\
Increase of 10\% light penetration & $1.01(1.00-1.03)$ & --- & $1.04(1.02-1.06)$ \\
Shifting from no slope to low slope & --- & --- & $4.07(0.78-21.20)$ \\
Shifting from low to intermediate slope & --- & --- & $8.49(1.72-41.87)$ \\
Shifting from intermediate to steep slope & --- & --- & $11.68(2.14-63.71)$
\end{tabular}
4 
Appendix A. Map of recorded sites in Loire and Isère departments.

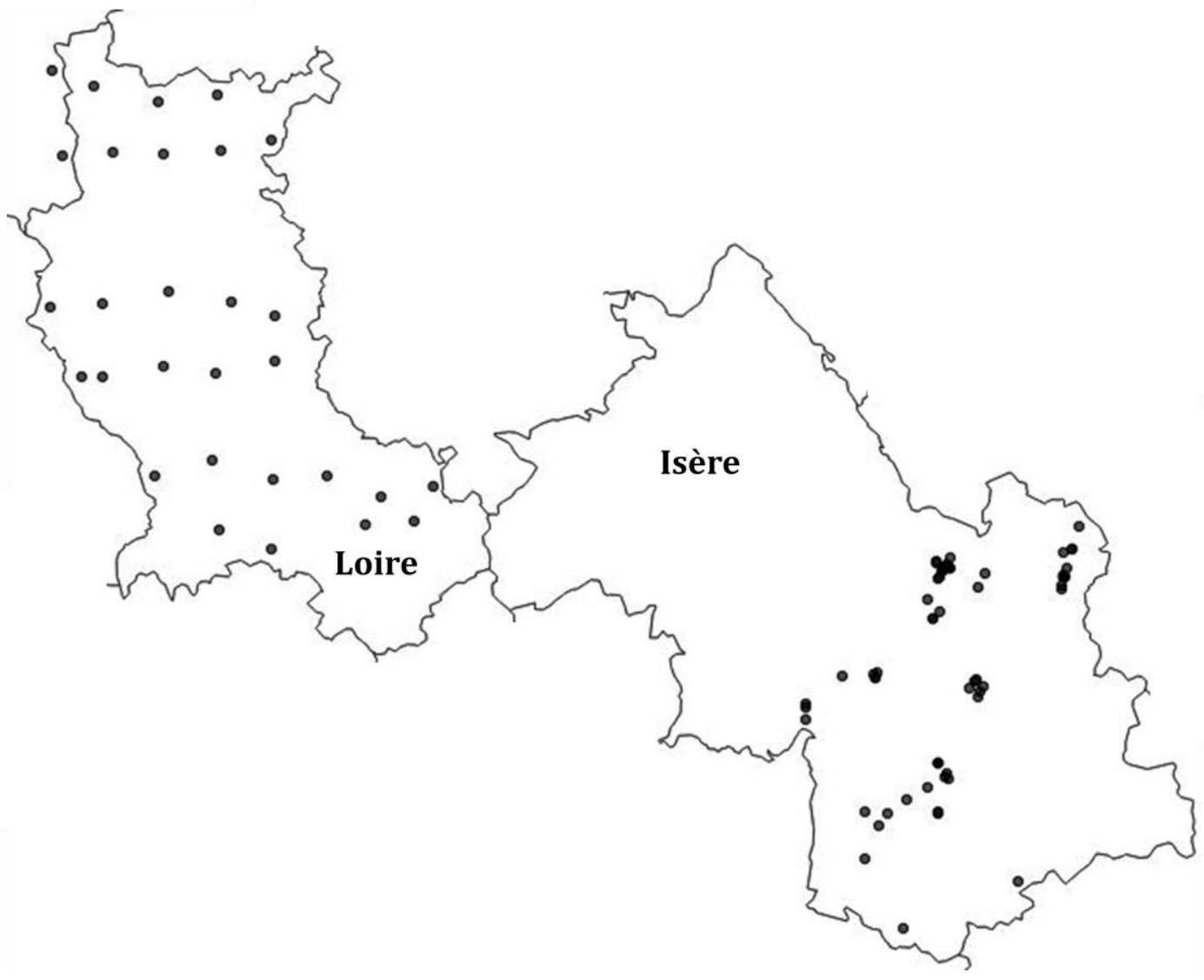

